\title{
Morphological, anatomical and antibacterial characteristics of Leonotis nepetifolia plants growing in Binh Thuan Province, Vietnam
}

\author{
Nguyen Thi Huong Giang ${ }^{1}$, Pham Van Ngot ${ }^{2}$ and Dang Thi Ngoc Thanh ${ }^{3, *}$ \\ ${ }^{1}$ Ben Cat High School, Binh Duong province, Vietnam. \\ ${ }^{2}$ Faculty of Biology, HCMC University of Education, Ho Chi Minh City, Vietnam. \\ ${ }^{3}$ Faculty of Natural Science Pedagogy, Sai Gon University, Ho Chi Minh City, Vietnam.
}

GSC Biological and Pharmaceutical Sciences, 2021, 14(02), 053-063

Publication history: Received on 25 January 2021; revised on 05 Februay 2021; accepted on 08 Februay 2021

Article DOI: https://doi.org/10.30574/gscbps.2021.14.2.0041

\begin{abstract}
Lion's ear [Leonotis nepetifolia (L.) R. Br.] is a Vietnamese medicinal plant that has been described in basic morphology and isolated for a number of chemical compounds. This study aims to supplement a database of morphology, microanatomy and antibacterial abilities of this species. Micro-anatomical analysis was based on a double staining method microscopic dimensional measurement of plant. The antibacterial capacity was based on the diameter of the inhibitory zone. The results showed that the plant had the characteristics of adapting to the dry and light conditions of the region. Leaf extract at the content of 4.8 to $8.0 \mathrm{mg}$ had the best inhibitory ability on 5 strains of bacteria B. cereus, $S$. aureus, E. faecalis, $P$. aeruginosa, and E. coli. The inhibition zone diameters were $0.27,10.33,5.00,3.80$ and $2.23 \mathrm{~mm}$, respectively.
\end{abstract}

Keywords: Binh Thuan; Folk remedy; Inhibitory zone; Leonotis nepetifolia (L.) R. Br; Micro-anatomy; Morphology

\section{Introduction}

Binh Thuan is a province in the Central Coast of Vietnam where the climate is dry, sunny and windy. This place is also the distribution of the Leonotis nepetifolia plant, which is suitable for light, wilderness, roadside and especially coastal areas [1, 2]. Pushpan et al. [3] made a review of medicinal uses of this plant in the folk remedies of India, Madagascar, Brazil, Canada, Kenya and many African countries. The uses of the plant were pretty much listed, including kidney disease, rheumatism, dysmenorrhea, asthma, and diarrhea. It was also thought to be a remedy with wound healing, antibacterial, anti-inflammatory, antipyretic, analgesic and anti-cancer effects. Among them, the most obvious uses were pain relief, anti-fever and anti-inflammation [3]. Dhawan et al. also synthesized documents showing that all parts of the Leonotis nepetifolia plant such as stems, leaves, roots, flowers and seeds had traditional medicinal uses [4]. Although related to the treatment of many such diseases, the Leonotis nepetifolia plant was only studied for a number of activities, including larvicidal and pesticidal activities, antioxidant potential, cancer cell inhibitory, and at most antibacterial activities [5, 6, 7, 8]. Some other studies have screened or isolated chemicals dissolved in petroleum ether, ethyl acetate, methanol, phytochemicals such as alkaloids, flavanoids, iridoid glycosides $[5,8,9,10]$. Leonotis nepetifolia plants growing in southern Africa were quite completely studied about systematic [11]. The roots and leaves of this species that grew in India and Brazil had also been studied for microanatomy [10,12]. However, in Vietnam, this species was described simply in morphology, origin, distribution, and utility [1, 2] and initially isolated some substances [9]. Therefore, this study aimed to complete more information on this species in the analysis of the adaptive morphoanatomical characteristics to the climatic conditions of the sampling sites and to initially investigate the antibacterial properties of crude ethanol extracts from stems, leave and roots of Leonotis nepetifolia plants growing in Binh Thuan, Vietnam.

\footnotetext{
* Corresponding author: Dang Thi Ngoc Thanh

Faculty of Natural Science Pedagogy, Sai Gon University, Ho Chi Minh City, Vietnam. 


\section{Material and methods}

This research work was carried out at the Ecology-Botany laboratory of the Faculty of Biology, HCMC University of Education and the Biochemistry-Microbiology laboratory of Saigon University from September 2019 to June 2020.

\subsection{Samples collection and preparation}

Binh Thuan is a province whose land ranges start to shift from south to west of the rest of Vietnam, with geographical coordinates from $10^{\circ} 33^{\prime} 42^{\prime \prime}$ to $11^{\circ} 33^{\prime} 18^{\prime \prime}$ North latitude, from $107^{\circ} 23^{\prime} 41^{\prime \prime}$ to $108^{\circ} 52^{\prime} 18^{\prime \prime}$ East longitude. In which, Binh Thanh is a commune in Tuy Phong district and Mui Ne ward is a famous tourist destination of Phan Thiet city. Binh Thanh commune has an area of $27.74 \mathrm{~km}^{2}$ and Mui Ne ward has an area of $35.41 \mathrm{~km}^{2}$ with a long coastline and many sand dunes [13] (Figure 1)

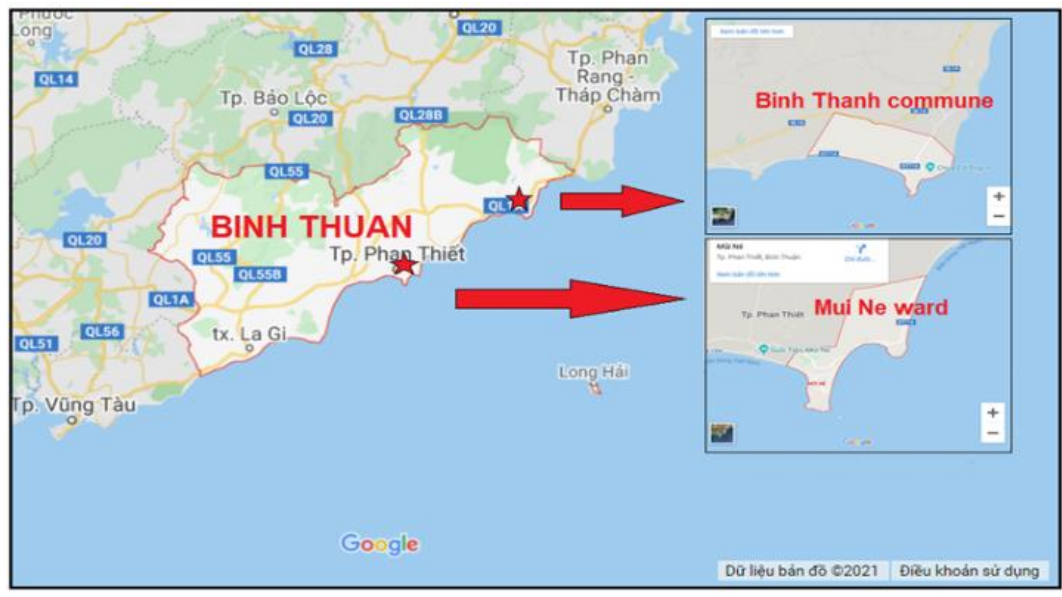

Figure 1 The map of Binh Thuan province and two sampling locations [13, 14]. Star shapes: Binh Thanh commune (Tuy Phong district) and Mui Ne ward (Phan Thiet city).

Sampling periods include September 2019, November 2019, and June 2020. Fifteen plant samples were collected from 5 sites in each location, 3 plants per site, which were used for anatomical analysis. Soil samples were also collected at the 5 sites. Soils were taken at the $0-20 \mathrm{~cm}$ layer as described in the Vietnamese National Standards TCVN 8551: 2010 and TCVN 7538-2: 2005TC [15]. In addition to the plant samples mentioned above, there were also 15 samples used in field research and many plants harvested for extracts. Plant and soil samples were transferred into sterile plastic bags, sealed, labelled, refrigerated and transported immediately to the laboratory. Fresh plant samples were stored in a refrigerator at $5^{\circ} \mathrm{C}$ for use in morphology and anatomy studies.

\subsection{Analysis of some climatic and soil conditions of the sampling locations}

Field survey indicators including coordinate location, light intensity, temperature and humidity were taken with the help of three devices including Garmin eTrex 10, Compact Light Meter LM-81LX and EXTECH RHT20. Field analysis was combined with hydro-meteorological forecasts of the area [16] to evaluate data at sampling time.

Soil particles and soil organic matter were analyzed according to the Vietnamese National Standards TCVN 8941-2011 and TCVN 8567-2010, respectively [15]. The place responsible for sample analysis was the Institute of Agricultural Science for Southern Vietnam, Ho Chi Minh City. The salinity, acidity and moisture of soil were determined according to the description of the Soil and Fertilizer Research Institute [17] and conducted in the laboratory.

\subsection{Analysis of morpho-anatomical characteristics of plant}

\subsubsection{Analysis of morphological characteristics}

Determining the Leonotis nepetifolia species based on the description of the documents [1, 2]. Morphological characteristics of the plant were recorded and photographed at the sampling sites. Plant height and stem diameter were measured in the field, with each location randomly selecting 15 samples for the survey. In the laboratory, the integral parts of these randomly selected plants were dried at $60^{\circ} \mathrm{C}$ until constant weight, then weighed. The vegetative and reproductive organs corresponding to the different developmental stages of the remaining samples (15 samples) were also analyzed further. 


\subsubsection{Analysis of anatomical characteristics}

The intermediate leaves, primary and secondary stems, and secondary roots were used in anatomical study. Thin slices of these parts were created with a razor and dyed twice as described by [18]. The sample was soaked in the javel for 15 minutes to purify the cell's endoplasm. The sample was rinsed with distilled water and then soaked in acetic acid $1 \%$ for about 5 minutes. After washing again with distilled water, the sample was dyed with carmin $4 \%$ for about 10 minutes and methylene blue $0.1 \%$ for about 10 seconds, with rinsing by distilled water between two staining phases. The sample was examined under a microscope after drop of pure glycerin to mount the slide.

The intermediate leaves (3rd and 4th leaves from the top of tree) was studied of stomata according to collodion film method [19]. The clean leaves were applied a layer of collodion to the surfaces, and when the layers dried, they were removed from the leaves and examined under a microscope.

\subsection{Investigation of the antibacterial ability of crude plant extract}

\subsubsection{Preparation of crude ethanolic extract}

The seperate parts of the Leonotis nepetifolia plant dried at $60^{\circ} \mathrm{C}$ until constant mass and then ground into fine powder. The powder was then soaked in absolute ethanol at a ratio of 1:3 (w/v) for 48 hours under room temperature. After soaking, the solution was clarified by filter paper to obtain the supernatant, and the residue continued to be soaked in alcohol as described above. The process was repeated again to ensure maximum recovery of the substances contained in plant powder. All volume of the ethanol extract was concentrated by using a rotary evaporator (Rotary Evaporator RE301, Yamato Scientific) to remove the solvent [20]. The extraction efficiency was defined as percentage by mass of extract relative to mass of original dry powder $(\mathrm{w} / \mathrm{w})$.

\subsubsection{Investigation of the antibacterial ability}

The antibacterial assay was performed according to agar well diffusion method [21]. The medium LB Agar was inoculated bacterial suspension to form concentration of $5 \times 10^{\wedge} 6 \mathrm{CFU}$ according to McFarland Standard and poured into the Petri plates. Four wells was prepared in each plate by using a sterile steel round pipe $(\Phi=0.6 \mathrm{~cm})$. Each of $20 \mu \mathrm{l}$ of the test compound $\left(70^{\circ}\right.$ alcohol-soluble extract, positive and negative controls) was injected into each well. The plates were incubated at $37^{\circ} \mathrm{C}$ for 48 hours. The result was obtained by measuring diameter of the inhibitory zone. The positive control was gentamycin $(0.5 \mathrm{mg} / \mathrm{mL}$ ) (Gentamicin Sulfate - Gentamicin $80 \mathrm{mg} / 2 \mathrm{~mL}$ - DOPHARMA, Vietnam) and tetracycline $(0.5 \mathrm{mg} / \mathrm{mL})$ (Tetracycline $500 \mathrm{mg}$ - Mekophar, Vietnam); and negative control was alcohol $70^{\circ}$. Tested bacteria were 5 strains of Bacillus cereus, Staphylococcus aureus, Enterococus faecium, Pseudomonas aeruginosa and Escherichia coli, provided by the Biotechnology Research and Development Institute, Can Tho University. Each treatment was repeated 3 times on 3 different Petri dishes.

\subsection{Processing statistics}

Statistics methods were ANOVA one factor and LSD test at $\alpha=0.05$ by using IBM SPSS Statistics 20.0.

\section{Results and discussion}

\subsection{Some climatic and soil conditions of the sampling locations}

The coordinates of Binh Thanh commune of Tuy Phong district and Mui Ne ward of Phan Thiet city were $11^{\circ} 13^{\prime} 12.4^{\prime \prime}$ North latitude, $108^{\circ} 40^{\prime} 22.6^{\prime \prime}$ East longitude, and $10^{\circ} 57^{\prime} 39.4^{\prime \prime}$ North latitude, $108^{\circ} 20^{\prime} 03.1^{\prime \prime}$ East longitude, respectively. The measured temperature, humidity and illuminance in the two above sampling locations were in the forecast range, $27.0^{\circ} \mathrm{C}-27.0^{\circ} \mathrm{C}, 75.5-79.1 \%, 52,000-100,000$ lux, respectively. The average temperature in June 2020 increased by $0.5-1^{\circ} \mathrm{C}$ over the same period last year due to increased lighting time and decreasing rainfall [16].

The soil profiles of the two sampling locations were shown in Figure 2. The soil layer $0-20 \mathrm{~cm}$ in Binh Thanh commune was sandy, reddish brown in color, dry soil, with discrete composition. Meanwhile, this layer in Mui Ne ward was also sandy soil type, gray in color, relatively discrete and mixed with gravel and roots. 


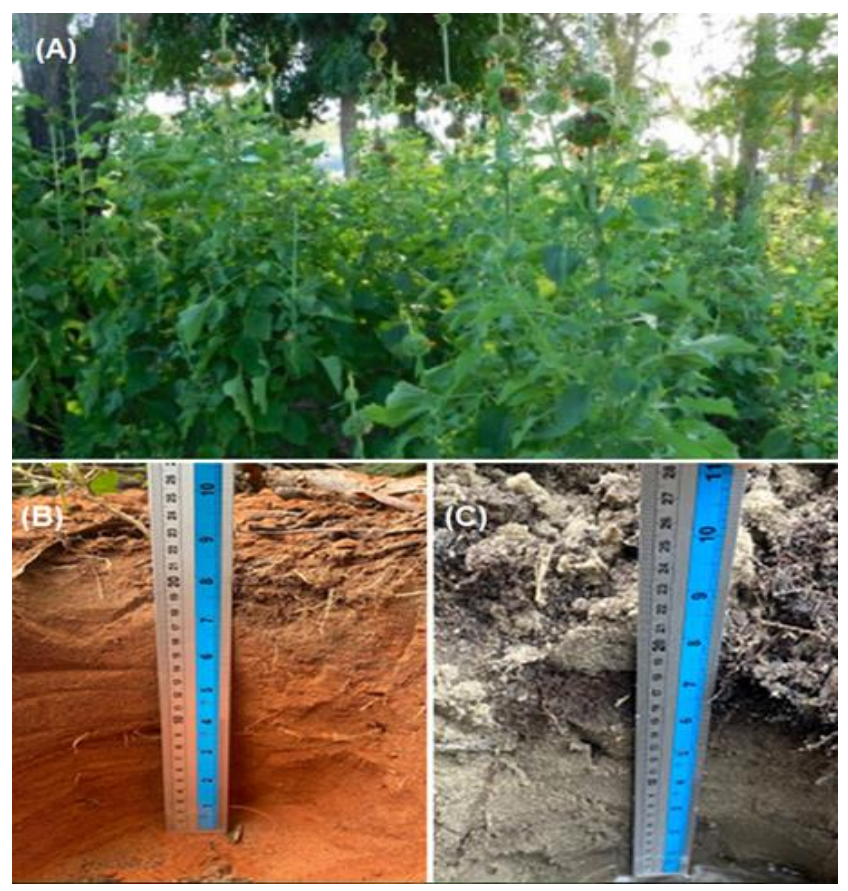

Figure 2 The landscape (Hon Rom in Mui Ne ward) where Leonotis nepetifolia distributed (A) and soil profile (20 cm deep) of Binh Thanh (B) and Mui Ne (C)

The results of analysis of the physical and chemical composition of the soil were shown in Table 1 . This showed that the both soils had a light mechanical composition, hygroscopic moisture, slightly acidic, and poor in organic matter. Soil in Binh Thanh was more cohesive due to clay ratio above 3\% and soils in Mui Ne were more inert due to higher EC. Given the soil and climatic characteristics of the region, how Leonotis nepetifolia plants need adaptive characteristics would be discussed next.

Table 1 Some physical and chemical criteria of soil samples

\begin{tabular}{|c|c|c|c|}
\hline \multicolumn{2}{|c|}{ Criteria of soil } & \multirow{2}{*}{$\begin{array}{l}\text { Sampling location } \\
\text { Binh Thanh } \\
\end{array}$} & \multirow{3}{*}{$\frac{\text { Mui Ne }}{98}$} \\
\hline \multirow{5}{*}{ Soil particles } & & & \\
\hline & Sand (\%) & 92 & \\
\hline & Silt (\%) & 3 & 1 \\
\hline & Clay (\%) & 5 & 1 \\
\hline & Organic matter (\%) & 0.80 & 1.24 \\
\hline \multirow[t]{2}{*}{ Soil acidity } & $\mathrm{pH} \mathrm{KCl}_{\mathrm{K}}$ & 4.43 & 4.85 \\
\hline & $\mathrm{pH}_{\mathrm{H} 2 \mathrm{O}}$ & 5.73 & 6.01 \\
\hline Soil salinity & $\mathrm{EC}(\mathrm{dS} / \mathrm{m})$ & 0.17 & 1.49 \\
\hline \multicolumn{2}{|c|}{ Soil moisture (\%) } & 22 & 43 \\
\hline
\end{tabular}

\subsection{Morphological characteristics of Leonotis nepetifolia}

The average height and stem diameter of Leonotis nepetifolia plants growing in Binh Thanh and Mui Ne were 107.79 and $103.80 \mathrm{~cm}$, and 0.85 and $1.12 \mathrm{~cm}$, respectively, but this difference was not statistically significant. In contrast, the dry biomass of the whole tree at the two sampling locations had a statistically significant difference, were 27.39 and 37.04 g per tree, respectively. In which, the ratio on the dry weight of the whole tree of the stems, leaves and roots were 71.8 and $54.7 \%, 17.6$ and $29.8 \%$, and 10.6 and 15.5\%, respectively. This showed that the Leonotis nepetifolia plants in Mui Ne had better growth and material accumulation than the plants in Binh Thanh. The growth of plants in the two locations was also different, with plants growing in Binh Thanh tended to grow better in the stem. 
Leonotis nepetifolia was a perennial semi-woody herb, average one meter tall, rarely branching (Figure $3 \mathrm{~A}$ ). The stem was square prism with 4 characteristic ridges (Figure $3 \mathrm{~B}$ ). Leaves were simple with a petiole about $1-1.5 \mathrm{~cm}$ long, arranged in the opposite decussate pattern, and had little hairs (trichomes) cover. The leaf blade (lamina) was broadly ovate with truncate or decurrent base, crenate margin, about $5-10 \mathrm{~cm}$ long and $2-5 \mathrm{~cm}$ wide. The venation was dichotomous and cross-venulate, slightly sunken on the adaxial but prominent on the abaxial of the lamina (Figure 3C). The roots extended both horizontally and vertically to enhance water and nutrient absorption. (Figure 3 D).

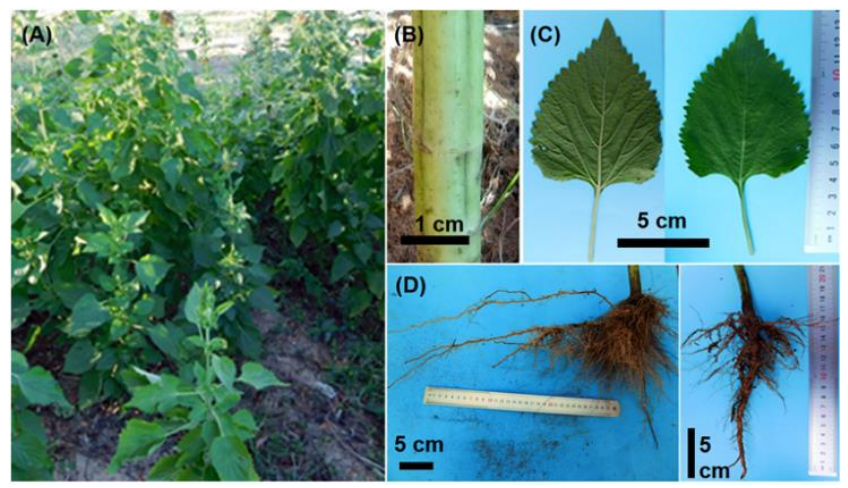

Figure 3 Morphology of vegetative organs of Leonotis nepetifolia plant

The inflorescences were mostly top, sometimes lateral if the plant was branching. They were panicle type (muchbranched inflorescence) with the peduncles about $25-40 \mathrm{~cm}$ long, consisting of $2-5$ sub-spherical flower clusters (verticillasters), separated by an internode up to $3-6 \mathrm{~cm}$ long. Each spherical sub-cluster had a diameter up to $5-8$ $\mathrm{cm}$, consisted of $50-70$ flowers.

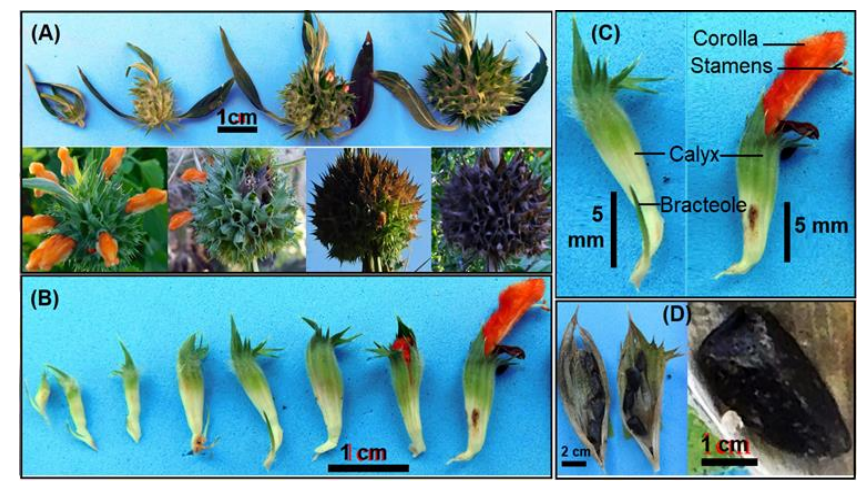

Figure 4 Morphology of reproductive organs of Leonotis nepetifolia plant Development stages of verticillaster (A) and flower (B); Flower (C) and Nutlets (D)

The two bracts of the sub-spherical flower clusters were $3-4 \mathrm{~cm}$ long, narrowly lanceolate, base attenuate, hairy like the leaves. The bracteole of each flower was $0.7-1 \mathrm{~cm}$ long, hard, linear, pointed, with many soft hairs. The flower had a short pedicel ( $0.5-2 \mathrm{~mm}$ long) and was characteristic shape of the Lamiaceae family with a size of $0.5 \times 3 \mathrm{~cm}$. The calyx was $1.5-2 \mathrm{~cm}$ long, consisting of sepals fused together to form a tube with a flaring mouth comprising 8 triangular teeth. A dorsal tooth was longest, 2 lateral teeth $(\times 2)$ and 3 ventral teeth united at base forming a recurved anterior lip. The outer surface of the calyx had 10 distinct longitudinal veins and many hairs. The corolla was tubular shape, $2-2.5$ $\mathrm{cm}$ long, orange in color, divided into 2 lips, with fine hair covering the outside. The upper lip had a lobe about $0.8-1$ cm long with dense outer hair. The lower lip (labellum) had 3 narrow lobes, in which the middle lobe was truncate or retuse at the apex. The androecium consisted of 4 stamens in which a pair was longer. Most of the length of the filament was attached to the corolla tube. The anther was bithecal with 2 microsporangia. The gynoecium comprised a superior 4 lobes-ovary with a gynobasic style and a bifid stigma. Fruits were 4 nutlets located in a calyx tube. Each nutlet was black, widely obovate shape with 3 corners and flat top, $3-3.5 \mathrm{~mm}$ long, $1.5-2 \mathrm{~mm}$ wide.

For the results on the size data of the external parts of Leonotis nepetifolia plants at the two sampling locations, there was no statistically significant difference. Compared with the description of the Vos and Kew Gardens [11, 22], the plants that grew in Binh Thuan, Vietnam was not much different from the plants of this species that grew in other regions of the world. The leaf base was truncate or decurrent instead of truncate or cordate as described in [11] 
In Vietnam and some other countries also used the species' synonym "nepetaefolia" [1, 10, 23], which needed to be adjusted for consistency.

\subsection{Anatomical characteristics of Leonotis nepetifolia}

\subsubsection{Anatomical characteristics of stem}

The results of micro-anatomy showed that the cross section of the primary stem was rectangular to square with 4 characteristic ridges (Figure $5 \mathrm{~A}$ ). Between the two sampling locations, the difference in data was not statistically significant, in which the epidermis was 12 - $13 \mu \mathrm{m}$ thick, the cortex was $109-114 \mu \mathrm{m}$ thick, and the stele was $1134-$ $1314 \mu \mathrm{m}$ thick, calculated by diagonal line. The epidermis that consisted of a layer of unequal polygons cells, had a thin cutinized layer in the outside. In addition, the epidermis had some scattered glandular and guard trichomes and a few of stomata (red arrow in Figure 5 B). Below the epidermis was the hypodermis consisting of 3 - 4 collenchyma layers, even growing into 8 - 10 layers at the ridges [(1) - (4) in Figure 5 A] to give stem mechanical strength. This was followed by 3 - 4 layers of parenchyma with spherical cells and conspicuous intercellular spaces. They all made up the cortex.
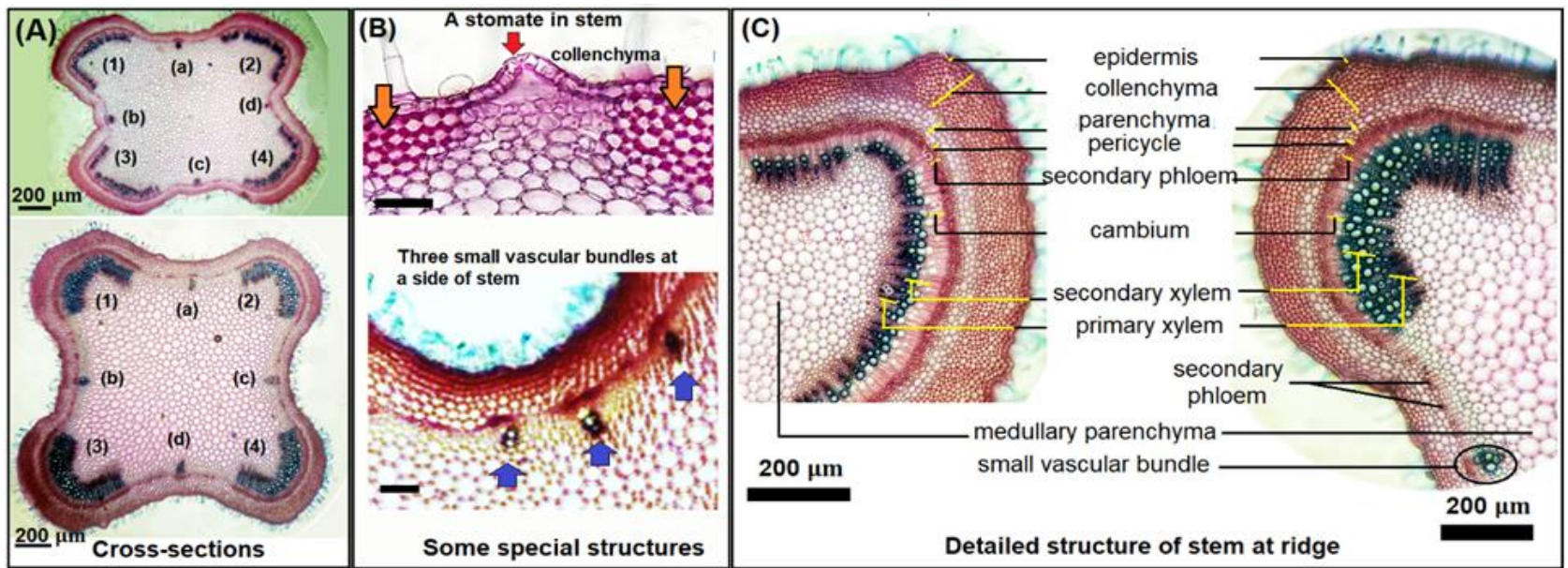

Figure 5 Cross-section of stems (A), some special structure (B), and detailed structure at ridges (C) $(1-4)$ : Four ridges; $(\mathrm{a}-\mathrm{d})$ : Vascular bundles at 4 midpoints of 4 edges

The stele was calculated from the pericycle (bundle cap) that consisted $3-4$ layers of polyhedron cells. The vascular bundles thrived at the four ridges [(1) - (4) in Figure $5 \mathrm{~A}]$ and were present at the midpoints of four edges [(a) - (d) in Figure $5 \mathrm{~A}$ ] which were sometimes more than a bundle (blue arrows in Figure $5 \mathrm{~B}$ ). Each bundle consisted of the outer phloem and the inner xylem that developed in the centrifugal direction. Between the phloem and xylem, the vascular cambium was present with 4 - 8 layers of cells fit closely arranged in concentric to form a continuous circle. Secondary phloem does not appear continuously at the edges. In particular, the activity of the cambium resulted in an early and increasing number of secondary xylem. The pith (medulla) located in the center of the stem, was composed of large parenchyma cells with small intercellular spaces (Figure $5 \mathrm{C}$ ). This observed stem organization of Leonotis nepetifolia resembled that described by [11]. The earlier stage of development of the primary stem should be studied further.

\subsubsection{Anatomical characteristics of leaf}

The general view of the cross-section of petiole was sub-orbicular with two small ears at adaxial side. The abaxial of the petiole and the midrib (from lower to upper) had a structure consisting of layers similar to the structure of the stem. However, the xylem of the petiole split into two parallel and symmetrical parts across one axis, but the xylem of the midrib was continuously arranged to form a sickle. Meanwhile, the phloem part of both was continuously arranged in an arc (Figure 6 A). Collenchyma tissue developed to $5-8$ cell layers at the edges of the petiole and on the adaxial of the midrib to increase mechanical strength. Meanwhile, the abaxial sides and two lateral sides of both had only $3-4$ collenchyma layers. 


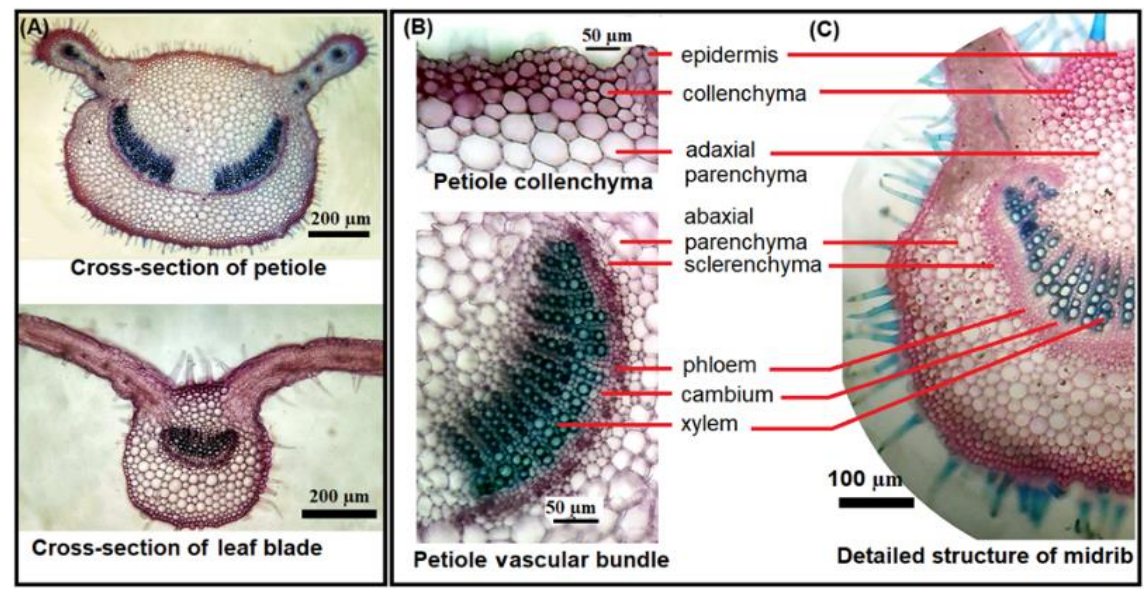

Figure 6 Cross-section (A), and detailed structure of petiole (B) and midrib (C)

For the leaf blade (lamina), the adaxial and abaxial epidermis had many uniseriate multicellular trichomes and thin cuticle about $2.2-2.3 \mu \mathrm{m}$ thick for protection. There were also some capitate glandular trichomes that were scattered and interspersed with epidermal cells, mainly on the abaxial side of the leaves (Figure 7)
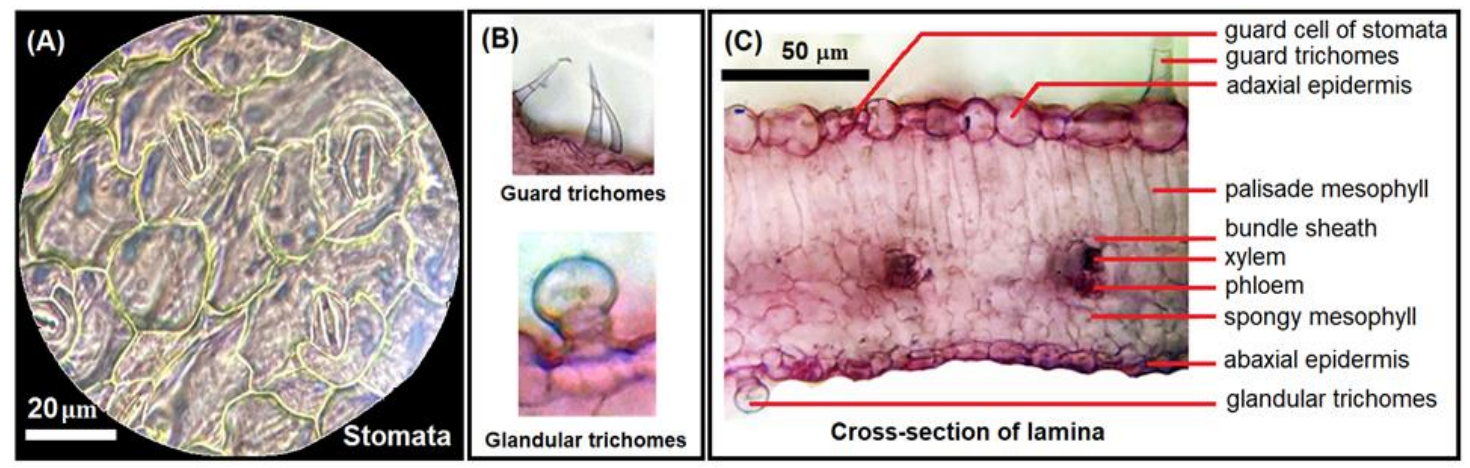

Figure 7 Diacytic stomata (A), trichomes (B), and detailed structure of lamina (C)

The epidermal cells were jigsaw piece-like shapes and irregular cell sizes. The adaxial epidermal cells were thicker than the abaxial epidermal cells, approximately 13.1 in comparison $11.12 \mu \mathrm{m}$ respectively. On both sides of the lamina, there were diacytic stomata with a density of about $188-209$ per mm2. The mesophyll consisted of $1-2$ layers of palisade cells in the adaxial and $3-4$ layers of spongy cells in the abaxial with the size of $36.5-44.3$ and $30.5-40.3 \mu \mathrm{m}$ thick, respectively. In the lamina, there were also lateral veins and veinlets. Each vascular bundle surrounded by $5-6$ parenchyma cells of bundle sheath with $2-4$ xylem cells located above and $6-8$ phloem cells below. The difference in leaf blade thickness of the two sampling locations was not statistically significant.

Compared with the description of the micro-anatomy of leaves in the documents [10,11], this study showed that the structures of petiole and midrib were not different. However, the leaf blade in this study had a clear differentiation between palisade and spongy mesophyll. In which, the palisade was thicker than the spongy that was different from the description of $[10,11,12]$. The guard trichomes was similar to that described by $[10,11,12]$, but the glandular trichome did not observe pattern 4-celled head clearly as described in [11]. The stomata in this study were defined as diacytic with the density lower than in [10]. The increase in the thickness of palisade mesophyll and the decrease in the number of stomata were probably the features adapted to the light conditions of this sampling locations.

\subsubsection{Anatomical characteristics of root}

The cross-section of the roots showed that the primary cortex had been peeled. The periderm consisted of $4-6$ indistinguishable layers, about $60-75 \mu \mathrm{m}$ thick. The secondary cortex was thin, accounting for about $1 / 4$ of the radius, mainly the secondary phloem, but medullary rays and cambium could not be seen clearly. The secondary xylem occupied most of the stele, approximately $600-710 \mu \mathrm{m}$ thick in radius, consisting of visible vessels and tracheids. Primary xylem and medullary parenchyma no longer existed. In the present study, the primary roots were not studied and could not distinguish the types of medullary rays as described in [10]. 

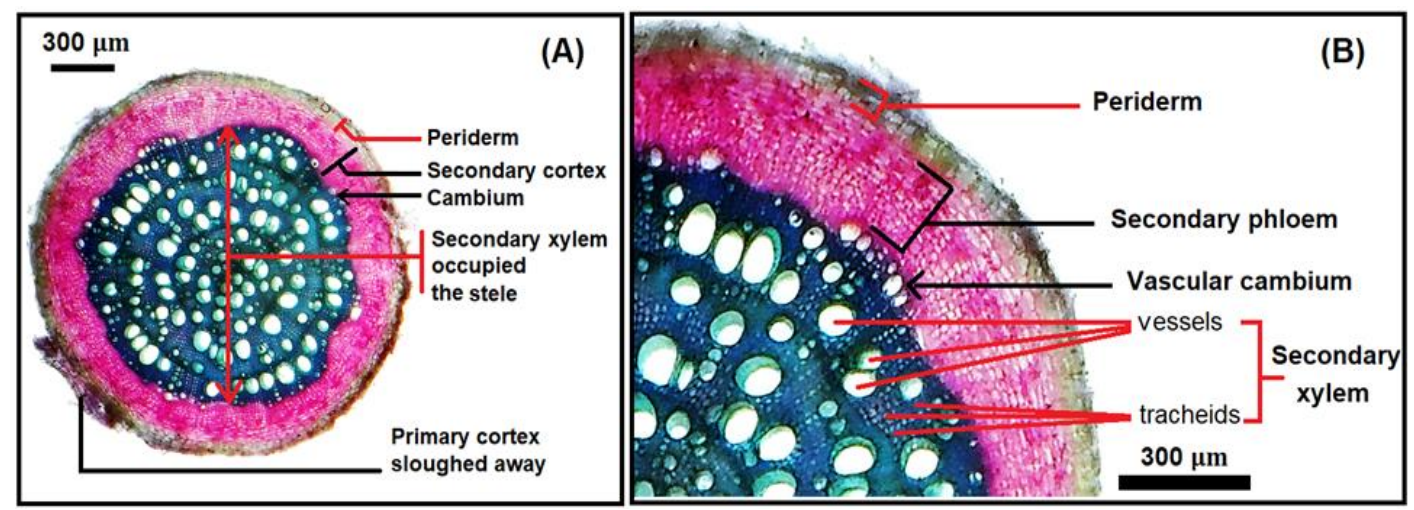

Figure 8 Cross-section (A) and detailed structure (B) of the secondary root of Leonotis nepetifolia

\subsection{Antibacterial ability of the crude plant extract}

\subsubsection{Characteristics of plant powder and extract}

The plant powder was observed under a microscope at 400 times magnification showing the presence of components such as sclerenchyma cells, trichomes, epidermis and stomata, and vascular elements. After immersion and extraction, the results of observing the extract under a microscope at a magnification of 100 times showed that light yellow crystal plaques had no certain shape and many fragments of plants that had unknown structure (Figure 9).

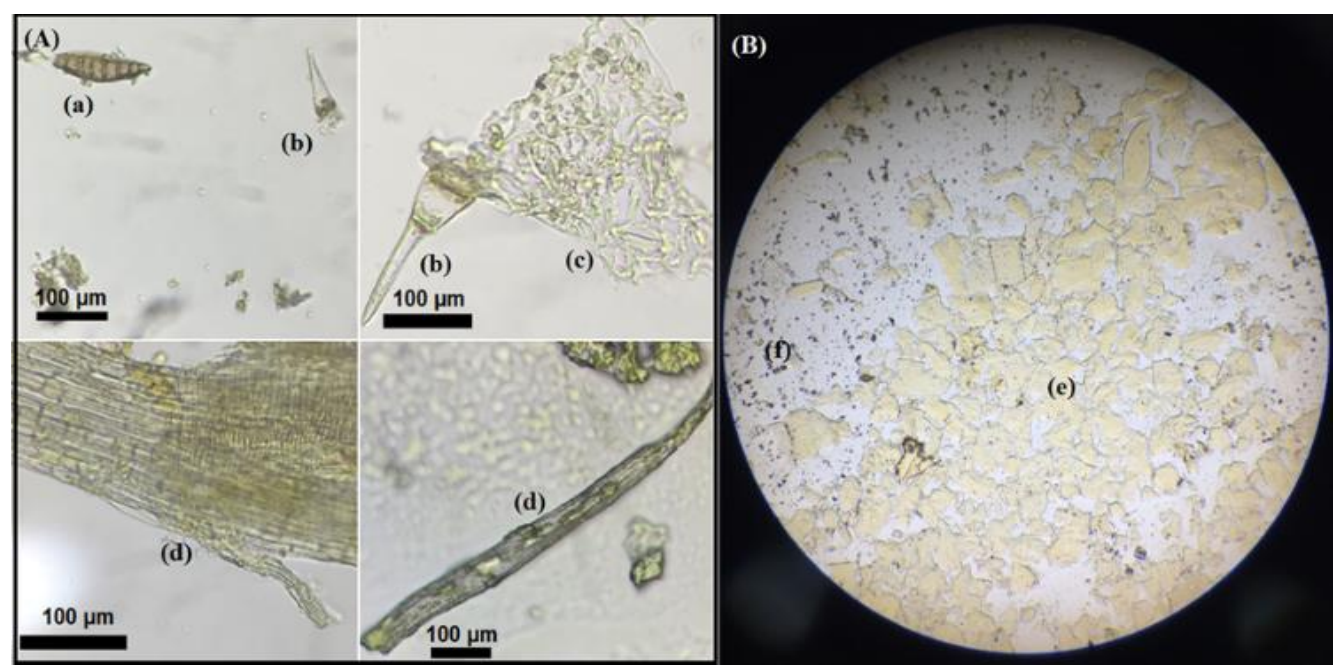

Figure 9 Leave powder $(\times 400)(A)$ and crude extract $(\times 100)(B)$ observed under a microscope (a): Sclerenchyma cells; (b): Trichomes, (c): Epidermis and stomata, (d): Vascular elements; (e): Crystal of ethanol extract; (f): Unknown fragments of plants.

The extraction efficiency of stems, leave, roots powder of Leonotis nepetifolia were 6.34, 6.12 and $6.72 \%$, respectively. The density of these extract were $1.21,1.16,1.02 \mathrm{~g} / \mathrm{ml}$, respectively. These solid extracts would be diluted in alcohol $70^{\circ}$ and then used in the antibacterial test.

\subsubsection{Antibacterial ability}

The difference in these indicators in the two sampling loactions was not statistically significant. The saturated concentration of the extract in alcohol $70^{\circ}$ was $400 \mathrm{mg} / \mathrm{mL}$. A range of concentrations had been created by diluting the saturated extract in alcohol $70^{\circ}$, consisting of $400,320,240,160$, and $80 \mathrm{mg} / \mathrm{mL}$. With a volume of $20 \mu \mathrm{L}$ of each well, the test extract contents corresponding to the concentration range were 8.0,6.4, 4.8, 3.2, 1.6 mg per well, respectively; meanwhile, the content of antibiotics Gentamicin or Tetracycline was $0.01 \mathrm{mg}$ per well. All samples extracted from stems, leaves, and roots of Leonotis nepetifolia growing in the two sampling locations at the concentration range mentioned above were tested on all 5 types of bacteria. However, the highest results for the inhibitory zone diameter would be analyzed and presented in Table 2. 
Table 2 Antibacterial activities of the ethanol extract of Leonotis nepetifolia

\begin{tabular}{|l|l|l|l|l|l|l|}
\hline \multicolumn{2}{|l|}{$\begin{array}{l}\text { Extract } \\
\text { (from samples) }\end{array}$} & \multicolumn{6}{l}{ Inhibitor zone diameter (mm) for bacteria } \\
\cline { 3 - 7 } & B. cereus & S. aureus & E. faecalis & P. aeruginosa & E. coli \\
\hline Stems & $(1)$ & 0 & $7.6 \pm 0.2$ & $12.6 \pm 1.4$ & 0 & 0 \\
\hline & $(2)$ & $9.3 \pm 0.1$ & $10.7 \pm 0.8$ & $16.1 \pm 0.8$ & $9.0 \pm 0.6(\mathrm{~b})$ & 0 \\
\hline Leave & $(1)$ & $10.5 \pm 0.1$ & $13.4 \pm 0.7$ & $10.2 \pm 0.3(\mathrm{a})$ & $16.7 \pm 0.5$ & $8.2 \pm 0.1(\mathrm{a})$ \\
\hline & $(2)$ & $16.3 \pm 1.6$ & $16.3 \pm 0.4$ & $11.0 \pm 0.4(\mathrm{a})$ & $9.8 \pm 0.4(\mathrm{~b})$ & 0 \\
\hline Roots & $(1)$ & 0 & $7.1 \pm 0.1$ & 0 & 0 & 0 \\
\hline & $(2)$ & $7.1 \pm 0.9(\mathrm{a})$ & $9.7 \pm 0.3$ & 0 & 0 & 0 \\
\hline Gentamicin* & $24.3 \pm 1.2$ & $28.2 \pm 1.1$ & $24.9 \pm 2.3$ & $25.5 \pm 1.7$ & $18.0 \pm 0.3$ \\
\hline \multicolumn{2}{|l|}{ Tetracycline* } & $16.3 \pm 1.5$ & $18.1 \pm 2.1$ & $17.0 \pm 2.3$ & $19.3 \pm 3.2$ & $32.1 \pm 2.2$ \\
\hline
\end{tabular}

The results presented in the Table were statistically significant at $\alpha=0.05$ according to the Duncan test; Extract content was $8 \mathrm{mg}$ per well; Antibiotic content was $0.01 \mathrm{mg}$ per well; (1): Samples collected in Binh Thanh; (2): Samples collected in Mui Ne; (a): The effect was statistically equivalent at a content of $6.4 \mathrm{mg}$; (b): The effect was statistically equivalent at a content of $4.8 \mathrm{mg} ;\left(^{*}\right)$ : The number of repetitions was 30. (-): Not tested.

Table 2 showed that there were differences in the antibacterial properties of extracts of different plant parts against the bacteria. In particular, leaf extract was effective on all five strains of tested bacteria while root extract was only effective on two strains of Gram-positive bacteria, B. cereus and S. aureus, and stem extract was only effective against all three strains of Gram-positive bacteria, and a strain of Gram-negative bacteria, P. aeruginosa.

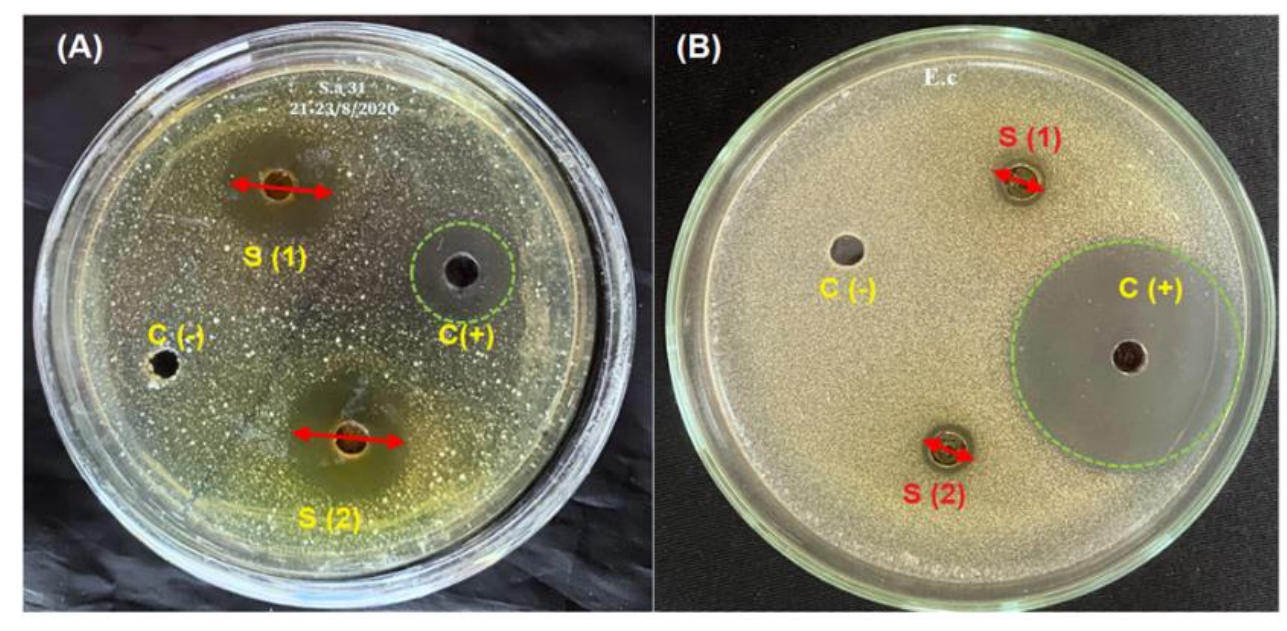

Figure 10 Inhibition ability of Leonotis nepetifolia leaf extract growing in Mui Ne against S. aureus (A) and E. coli (B)

(S): Samples (8 mg per well); (C -): Alcohol 70; (C +): Tetracycline (0.01 mg per well).

The stem and leaf extracts of the Leonotis nepetifolia plants growing in Mui Ne were best resistant to P. aeruginosa at $4.8 \mathrm{mg}$ with inhibitory zone diameters of 2.20 and $3.47 \mathrm{~mm}$, respectively (Data was not shown in the Table 2). This difference was not statistically significant compared to the higher concentration, therefore, it was shown that the extract has a good inhibitory effect on this bacteria. Both stem and root extracts had no effect on $E$. coli and neither was leaf extract from Leonotis nepetifolia growing in Mui Ne. Between extract samples obtained from the two sampling locations also showed different resistance to the tested bacteria. This proved that the active substances of Leonotis nepetifolia plants growing in two different ecological regions could be different and this result needed to be studied further to determine whether the difference was due to genetic capital between different populations or due to habitat effects. However, differences in the antibacterial properties of Leonotis nepetifolia extracts on different bacteria had been observed [7, 8]. In which, S. aureus or B. cereus were bacteria more easily inhibited than P. aeruginosa or E. coli, but depended on extraction method or the plant parts of the sampling. This present study had not shown clear resistance to $E$. coli as the results of $[7,8]$ and therefore required further investigation. 


\section{Conclusion}

Leonotis nepetifolia plants growing in the two districts of Binh Thuan province showed only statistically significant differences in the dry matter content. They also had slight variation in leaf mesophyll tissue structure from current publications on this species in some areas of the world. Morpho-anatomical characteristics of the plant showed suitability to the climatic conditions of the habitat. The crude ethanol extract from the leaves was effective against all 5 bacterial strains tested.

\section{Compliance with ethical standards}

\section{Acknowledgments}

The authors would like to thank for the support of Ho Chi Minh City University of Education and Saigon University.

\section{Disclosure of conflict of interest}

All authors declare no conflicts of interest associated with this article.

\section{References}

[1] Pham Hoang Ho. Plants used as medicinal herbs in Vietnam. HCMC: Youth Publishing House; (Language: Vietnamese). 2006.

[2] Vo Van Chi. Vietnamese Medicinal Plants Dictionary, Volume 1. HCMC: Medical Publishing House; (Language: Vietnamese). 2018.

[3] Pushpan R, Nishteswar K, Kumari H. Ethno medicinal claims of Leonotis nepetifolia (L.) R. Br: A review. International Journal of Research in Ayurveda and Pharmacy. 2012; 3(6): 783-85.

[4] Dhawan NG, Khan AS, Srivastava P. A General Appraisal of Leonotis nepetifolia (L) R. Br: An Essential Medicinal Plant. Bull. Env. Pharmacol. Life Sci. 2013; 2(8): 118-21.

[5] Udaya Prakash NK, Bhuvaneswari S, Balamurugan A, et al. Studies on antibacterial, antioxidant, larvicidal, pesticidal activities and phytochemistry of Leonotis nepetifolia (Linn) R. Br. Int. J. Res. Pharm. Sci. 2013; 4(2): 303-09.

[6] Veerabadran U, Venkatraman A, Souprayane A, Narayanasamy M, Perumal D, Elumalai S, Sivalingam S, Devaraj V, Perumal A. Evaluation of antioxidant potential of leaves of Leonotis nepetifolia and its inhibitory effect on MCF7 and Hep2 cancer cell lines. Asian Pac J Trop Dis. 2013; 3(2): 103-10.

[7] Narayan SS. Antibacterial potential of crude methanolic extract of Leonotis nepetifolia (L) R. Br. International Research Journal of Pharmacy. 2012; 3(2): 277-78.

[8] Gnaneswari K, Venkata Raju RR. Preliminary phytochemical screening and antimicrobial evaluation of Leonotis nepetifolia (L.) R. Br. J. Nat. Prod. Plant Resour. 2012; 2(6): 689-692.

[9] Do Thi My Lien, Nguyen Kim Phi Phung, Tran Ai Diem, Nguyen Thi Nhung, Le Cong Nhan, Nguyen Xuan Du, Nguyen Thi My Dung. Identification of compounds from ethylacetate of Leonotis nepetifolia (L.) R.br. (Lamiaceae). Journal of Science Technology and Food. 2020; 20(2): 62-71.

[10] Ashish T, Neeraj Sethiya K, Mishra SH. Preliminary pharmacognostic and phytochemical analysis of "Granthika" (Leonotis nepetaefolia): An Ayurvedic herb. Indian Journal of Traditional Knowledge. 2011; 10(4): $682-88$.

[11] Vos WT. A systematic study of Leonotis (Pers.) R. Br. (Lamiaceae) in southern Africa [PhD of Botany]. Pietermaritzburg: University of Natal. 1995.

[12] Procópio SOI, Ferreira EA, Silva EAM, Silva AA, Rufino RJN. Anatomical studies of leaves in weed widely largely occurring in Brazil. V - Leonurus sibiricus, Leonotis nepetaefolia, Plantago tomentosa and Sida glaziovii. Planta Daninha. 2003; 21(3): 403-11.

[13] Binh Thuan Portal [Internet]. Binh Thuan: Binh Thuan Provincial People's Committee. (C) 2020.

[14] Map Data [Internet]. California: Google. (C) 2020. 
[15] Vietnamese National Standards - Technical regulations [Internet]. Hanoi: Portal electronic of the Ministry of Agriculture and Rural Development. (C) 2020.

[16] Hydro-meteorological news [Internet]. Hanoi: Vietnam Meteorological Hydrological Administration. (C) 2019.

[17] Soils and Fertilizers Research Institute. Handbook of soil, water, fertilizer, crop analysis. Hanoi: Agriculture Publishing House; (Language: Vietnamese). 1998.

[18] Tran Cong Khanh. Practice of plant morphology and anatomy. Hanoi: University and Professional High School Publishing House; (Language: Vietnamese). 1981.

[19] Nguyen Nghia Thin. Methods of Plant Research, 2nd ed. Hanoi: Vietnam National University Publishing House; (Language: Vietnamese). 2008.

[20] Nguyen Kim Phi Phung. Methods of Isolation of Organic Compounds. HCMC: Vietnam National University Publishing House; (Language: Vietnamese). 2007.

[21] Balouiri M, Sadiki M, Ibnsouda SK. Methods for in vitro evaluating antimicrobial activity: A review. Journal of Pharmaceutical Analysis. 2016; 6(2): 71-79.

[22] Plants of the World Online [Internet]. London: Royal Botanic Gardens Kew. (C) 2017.

[23] Elías Piedra-Ibarra E, Torre-Almaráz RDL, Zúñiga G, Xoconostle-Cázare B, Ruíz-Medrano R. Leonotis nepetaefolia: An important plant virus reservoir in central Mexico. Phytoparasitica. 2005; 33: 480-94. 